\title{
INITIATING SUSTAINABLE PERFORMANCE ON LANGUAGE CURRICULUM IMPLEMENTATION
}

\author{
Didik Rinan Sumekto ${ }^{1}$
}

\begin{abstract}
The fundamental measurement of language curriculum performance initially reflects to some supporting processes during its implementation, in which it involves the stakeholders progressively. It is a mutual understanding that the language curriculum implementation requires a highly collaborative dynamics to any existing changes in the society. The real commitment and consistence of implementing the curriculum, in the later, as one aspect criteria to measure its success. Therefore, schools as the most ultimate institution of implementing this curriculum will have a challenging task and responsibility to reach out and to prove the achievements with all resources availability and limitation.
\end{abstract}

Key Word : curriculum, evaluation, educational reform, performance

\section{INTRODUCTION}

Curriculum is currently configured according to the elements of a cultural heritage that are deemed worthy of transmitting or communicating to a new generation of learners. It draws upon the past but it shapes according to the future. A curriculum is more than a vision; is shaped by its users, both those who wield it and those whose lives are managed or steered, according to its prescriptions. Moreover, a curriculum is more likely to reflect the cultural selections, values and aspirations of powerful social groups than the cultural assumptions and aspirations of powerless groups.

An ideal curriculum is both a blueprint for future and as important, a set of procedures for realizing such goals. To this extent, curriculum design, construction and implementation are the multifaceted production process. Nowadays, current educational theory tends to define curriculum as the "what" of education and teaching and learning jointly as the "how" of education. It suggests that there is a much closer relationship between the ways in which curricula are constructed and the pedagogic openings that they offer to teachers and learners. Since every curriculum can be structured in many ways, each with a different educational potential and by the same token, the potential of curriculum can be released in many ways, e.g.: via lectures or seminars, and grasped in many ways, e.g.: by rote learning or guided discovery (Hamilton, 1990).

Furthermore, Wray (1995) contributes his judgement that curriculum design can be seen as a kind of writing activity and as such it can usefully be studied as a process. The typical sub-processes of the writing process, such as gathering ideas, ordering ideas, ideas to text, reviewing, editing can be applied to curriculum design, but it makes it easier to draw on current curriculum design theory and practice if a different set of parts is used. In viewing this

English Education Study Program Lecturer, Widya Dharma University, Klaten. E-mail: didikrinan@unwidha.ac.id 


\section{Intianting Sustainable Performance on Language Cirriculum Implementation}

contribution, thus, Ross (2004) emphasizes that the effect on the curriculum is to value processes and content that are amenable to grading. This can mean that a curriculum is, at least in part, determined by its ability to filter, such as knowledge and skillstraditionally knowledge in particular that are relatively inaccessible are given a more important place, because they will make it easier to construct filters that achieve the desired result.

\section{STANDARDIZED CURRICULUM}

The professionalized curriculum generallynow consists of one or more national languages which the reality that local languages and dialects are relatively down graded in the teaching of a nation-wide language. What variation that there is in language policy tends to be on matters such as which languages are to be regarded as official; how much use might be made of local languages or mother-tongue teaching in the early part of the schools; the methods and emphases used in language teaching; and whether and how to legitimize local languages. This core area was generally taught either under the combined social studies rubric, or divided into separate subjects, such as history, geography and civics education (Saroyan and Amundsen, 2004).

Real content denotes pedagogical aims, such as the features of language the learners will hopefully become more aware of or be better able to produce or the language skills they gain control of. Carrier content denotes, as its name suggests, the means of delivering the real content. These means include the use of texts or activities. For example, if we were teaching an English for Special Purposes (ESP) class for financial accountants, and if one of our pedagogic aims was to familiarize our learners with vocabulary used in financial reporting, we might use a company's annual report as a text to 'carry' the content of interest. This text can be used as carrier content in an ESP class focusing on vocabulary related to finance. In the lesson, students may be asked to read the text and identify how the items 'cash', 'capital' and 'debt' are used. For example, they could be asked to discuss the meaning of collocations involving 'capital', such as 'capital expenditure', 'capital raising' and 'capital notes'. Focally, the ESP learners might develop an integrated skills activity in which students read company annual reports and make notes on the types of assets listed by preparing an oral report (Zajda and Geo-Jaja, 2010).

A major consideration in planning a syllabus is the question of what content shall be included in the course. Asyllabus is generally organized in units. The units might be construed as areas of grammar and/or vocabulary, genres, language functions (speech acts), notions, skills or strategies. The needs analysis involves multiple methods and sources of information and suggests that the course needed to provide a communicative component in which students will be able to adapt their current general English into English knowledge for business situations. The course is also needed to consider cultural issues in communication with other learners or users and provide realistic or authentic samples of language use (Cowling, 2007; Basturkmen, 2010). In planning the syllabus, teachers or course designers make decisions about what to include in terms of types of units such as skills, vocabulary, genres, functions, notions and disciplinary, professional or cultural content items in the units, such as which genres, semantic sets and functions; sequencing-what should come first, second and so forth and decisions made according to considerations, such as immediate and less immediate need, level of difficulty with easier items before more difficult items and logical flow-for instance, in 
Business English, opening meetings before closing meetings (Zajda and Geo-Jaja, 2010).

Herewith, developing materials will talk about the term 'authentic' denote that the texts were written for purposes other than language teaching and learning. Harding (2007; Basturkmen, 2010) offers two useful advices in this regard, namely: use contexts, texts and situations from the students' subject area. Whether

they are real or simulated, they will naturally involve the language the students need; exploit authentic materials that students use in their expertise or vocation-and don't be put off by the fact that it may not look like 'normal English'. The authentic texts play an important role in demonstrating 'real' language use. If we aim to demonstrate to our class of nursing students the forms and features of nursing care plans, we would generally wish to show the class samples of authentic care plans. One text may have the looked-for rhetorical structure and linguistic exemplification, but the content is too obscure or unmanageable; another has attractive and utilizable content (Myers, 1990; Basturkmen, 2010).

Figure 1 below shows us about the role of course design.

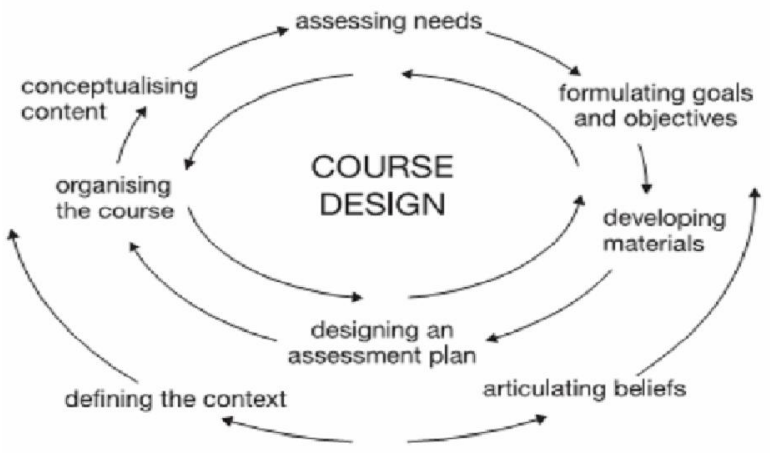

Figure 1. Model of standard curriculum design (Graves, 2000; Nation and Macalister, 2010)
Curriculum development involves planning a course at the outset but it also involves ongoing course revision. In deciding whether to revise a course, the developer first needs to know how effective the present version of the course is. One key source of information is students' course evaluation. Teachers in many contexts around the world will be familiar with the kinds of during or end-of-course evaluations that are used, often questionnaires or interviews eliciting end users', students' and sometimes teachers' perceptions of the effectiveness of the course. Perceptions of effectiveness are part of the portrait. Another part is students' response to the course and learning fromit. The course designer needs to consider did the students like the course and did they learn anything from it? (Basturkmen, 2010).

\section{IDEA OF CURRICULUM ENGINEERING}

Curriculum, what teachers teach and what students learn, is usually focuses on subject content and the teaching of basic skills, of reading, writing, speaking and listening that allow students to communicate what they learn and enable them to learn more. Today, however, the concept of curriculum needs to expand to include the explicit teaching of the intellectual and social-emotional skills. Instead of the pre-processed curriculum that too often lacks the intellectual nutrients needed for complex learning, students need curriculum that demands their thinking, requires them to problem solve together, encourages them to persevere, and teaches them the skills to organize and evaluate their learning. Student-centered classrooms focus on student interests, feature more choices, and include a variety of hands-on project work. In a traditional classroom, the focus is on learning content and basic skills. In a student-centered classroom, content and basic skills are also a priority, 


\section{Intianting Sustainable Performance on Language Cirriculum Implementation}

but they are taught in ways that take into account student interest, choice, creativity, and a wider range of learning processes (Blumenfeld et al, 1991; Darling-Hammond, 1997; Dewey, 1964; Folsom, 2005; Thomas, 2000; Folsom, 2009). Classrooms where complex teaching and learning take place have all the features of a learners-centered classroom and a focus on basic skills. In addition to this balance, teachers consciously plan the curriculum to include the explicit teaching of thinking and social-emotional processes integrated with content (Folsom, 2005; Folsom, 2009). In these classrooms, teaching students to set criteria that guide decision making, planning projects, cooperatively solving problems, and selfevaluation are also basic skills (Folsom, 2009).

\section{CURRICULUM IN GLOBALIZATION ERA}

Since educational aims are achieved through learning, the curriculum process is described by those factors that bring about learning. Thus, both learning and instruction are central to the curriculum process. Informal changes may be made to the curriculumby teachers without the formal assent of the accrediting agency, and often are. Teachers may leave out or add to the material, or change the way in which it is taught and assessed by them. In technological subjects, teachers' often have to make changes to the content. Rather like automobiles the curriculum is subject to a continuing process of minor change. But these changes, which while from the teachers' perspective provide for continuous quality improvement, do not form the formal perspective that is the subject of quality assurance. Every now and again the accumulation of these changes makes necessary a major review of the curriculum and some departments do this irrespective of external pressures. For its delivery the curriculum is dependent upon teachers who function within some kind of unit that gives coherence to the subject being taught. For its delivery the curriculum is dependent on cohesion among the members of the team, and if there are tensions between team members learning may be impeded. A mission statement shall be the emotional hook on which an institution hangs its clothing. Because mission statements lack substance they come to be disregarded by both faculty and students. The linkage between them and the reality of the institution is broken. Sometimes they are expressions of hope about how students will develop. However, it is detected in the way students tackle problems based on both syllabus content and the way they behave in coursework (Saroyan and Amundsen, 2004).

\section{EDUCATIONAL REFORM: ADVANTAGES AND DISADVANTAGES}

The quality and accountability in education increasingly turn to international and comparative education data analysis. All agree that the major goal of education is to enhance the individual's social and economic prospects. This can only be achieved by providing quality education for all. The steps focused on the design of a particular "representative" school that best reflected the most pressing needs of the modernizers. Building on this first venture these same modernizers and their successors added other schools to respond to other needs-for different skills, regions, and interested groups. It is common, when considering major educational reforms, to create consultative bodies that include representatives from the various political parties, the different levels of education, and the different working groups involved in educational practice such as the principals' association, the teachers' union (Zajda and Geo-Jaja, 2010). 
Popkewitz (1988; Zajda and Geo-Jaja, 2010) strengthens that the educational reform seems to involve change, in fact, it may serve as a kind of ritual, which provides a powerful symbolic form of legitimating, giving the appearance of scientifically controlled change and masking the current ways in which the status quo is reproduced. It is defined 'change' as a process involving the continual clash of traditions, material conditions, and cultural forms as people act to sustain and to generate their social worlds. It involves an interrelation of factors of social structure and forms of consciousness, while 'reform' represents a normative concept, which attempts to legitimate the ongoing power relations of schools in a manner that makes those relations seem to benefit all rather than a few. The educational reform includes a modern foreign language for all learners among the 'foundation' subjects in curriculum. The text makes no specific reference to diversification; it provides, as the curriculum language relates to the key stages specified by which the languages will qualify as a foundation subject that has been selected. Therefore, the first modern language studied should (1) extend the learner's linguistic knowledge, skills and understanding; (2) lay a foundation for learning any subsequent languages; (3) widen the learner's cultural horizons and promote international understanding; and (4) be of practical value in future employment, for trading purposes, or in adult life more generally (Phillips and Sankey, 1993). Zajda and Geo-Jaja (2010) point out that for a change in education to count as a reform it must seek, and have good prospects of achieving, improvements whether in the quality of learning, teaching and growth of knowledge and understanding, which are our central concerns in education, or in the conditions that support and sustain learning, teaching, scholarship, research and the diffusion of knowledge. Thus, educational reform is merely a matter of the instrumental uses of institutions and processes to serve whatever objectives a particular social order or group fixes upon, however valid they may be in their own right.

The advantages of educational reforms have been depicted as focused on changes in the following aspects of educational systems, such as (1) number of students, teachers, administrators, and buildings; (2) objectives; (3) policy making and the administrative or managerial system; (4) financing and budget-making process; (5) level of funding; (6) system organization; (7) curriculum; (8) pedagogy; (9) selection, evaluation, and promotion criteria and procedures for students and people involved with the educational systems-teachers, administrators, etc (Ginsburg, 1991; Ginsburg et al. 1990; Sack, 1981; Zajda and Geo-Jaja, 2010). Critical theorists believe that one of the main goals that shall be pursued by educational reforms is to eliminate social inequalities within educational systems and society in terms of race, gender, and social class, which implies to avoid differential access to schooling and to guarantee that economically disadvantaged students will be able to access to the system so that they could compete under equal conditions with students of other socioeconomic groups (Bowles and Gintis, 1976; Carnoy and Levin, 1976; Zajda and Geo-Jaja, 2010). Accordingly, the social justice and fairness represent key issues at the moment in of evaluating any kind of educational reform. The success of an educational reform is associated with different factors, including equality provision of educational opportunities, resources and materials, and appropriate environments.

Equally, the control or management of educational reform must be of significant interest to the community at large, to the social and cultural leaders and to governments that represent the people. 


\section{Intianting Sustainable Performance on Language Cirriculum Implementation}

In short, educational reform is a partnership and most especially of interest to those which have a responsibility for the governance and for the institutions and mechanisms upon which our social and individual well-being depend. Therefore, to support these institutions and mechanisms, there are four stages of educational reform (Saleh, 1995) in the following: (1) the emergence of new ideas and possibilities for change; (2) the formulation of policies; (3) program implementation; and (4) monitoring and evaluation.

On the other hand, the educational reforms are indispensable to achieve a successful reform; otherwise is not possible to have an educational reform, which moves toward a more equal and fair society that satisfies the needs of all social groups. It means that if a reform in any schools system worldwide attempts to promote equal access, then high school graduate students belonging to different socio-economic groups should be allowed to apply for entrance, if they are interested, under equal conditions. The notion of failure, given explicit and implicit functions of an educational reform is direct consequence of problems latent in capitalist societies where social inequalities and social relations of production have been reproduced over time. Indeed, the critical theory perspective believes that recurring reforms seldom transform educational institutions because elites never plan or execute them to do so. In this respect, it has been argued that there are four relevant factors to understand why educational reform rhetoric and action are not completely achieved: (1) insufficient commitment to produce changes by elite groups who look to legitimate their political power (Campbell, 1982; Zajda and Geo-Jaja, 2010); (2) limited support of local economic elites and powerful groups outside the country (Altbach, 1982; Carnoy, 1976b; Zajda and Geo-Jaja, 2010); (3) funding constraints due to societies and states being affected by economic and fiscal crisis; and (4) opposition or resistance of social actors, such as educators and parents, to change efforts promoted by elites (Ginsburg, 1991; Zajda and Geo-Jaja, 2010).

\section{TEACHER'S EMPOWERMENT IN EDUCATIONAL REFORM}

The curriculum has required schools to plan its implementation and to consider the curriculum across the school as a whole. It has led to greater teacher participation in whole school planning, in which the teachers and schools have had to adapt their plans as a result of changes in national policy, circumstances which at least show that the government has been prepared to make changes in the light of schools' experience (Thomas and Martin, 1996). In supporting the teachers' role, Newman (1979; Jarvis, 2004) characterizes that the multifarious roles of educators as: (1) entrepreneurs-they have to establish courses and then ensure that there are sufficient students to make them viable; (2) wheelerdealers-they have to overcome all the problems of entrepreneurs employed in a bureaucratic education service; (3) administrators-they are responsible for planning programmes and employing staff; (4) managers-their job is to manage the part-time staff and the educational premises; (5) animators-they have to make things happen; (6) trouble-shooters-they have to deal with the multitude of problems that complex organizations like adult education institutes create; (7) experts on method-they might be called upon to provide guidance and assistance to part-time adult education staff; and (8) campaigners-since adult education, as a marginal branch of education, is always under threat. According to Wray (1995) that 
almost invariably, when school work is organised around the ubiquitous project, will be expected that the teaching of English language will play a major role by being embedded in the teaching of other subjects. English teachers try to open up this idea of embedding English language work into projects and examine to what extent it might be possible to do justice to the English elements of integrated work. One of the major points, if English language work is to receive the level of attention it deserves and needs, that schools and teachers take a deliberate approach to planning it into their project work, in whatever area of the curriculum this is located. Saleh (1995) strengthens that an understanding of curriculumas a (deconstructed) text acknowledges as pre-eminently historical. Herewith, history is not understood as ideologically constructed, rather as a series of narratives superimposed upon each other, interlaced among each other, layers of story merged and separated. To understand curriculum as a (deconstructed) text is to tell stories that never end, stories in which the listeners, the "narratee", may become a character or indeed the narrator, in which all structure is provisional, momentary, a collection of twinkling stars in a firmament of flux.

Teacher's roles in developing a curriculumcan be implemented through the working of concept maps, for example, in the workshop may resemble one of the formats mutually designed. The teachers use an unstructured form of concept mapping to allow the utmost freedom to represent their thinking. The purpose is to uncover the participant's thinking about the overall concepts in the course, the nature of the relationships among these concepts and the course as a whole. Thus, teacher pays attention to both the internal integrity (representation of concepts and links among them) and the external integrity (overall structure and shape) of the concept map. The true test of the comprehensiveness of a concept map is that a teacher can see every key element of his or her course in the map and can use it to effectively describe the course to someone else. Each example provided in the figures that appear later in the chapter reflects the unique perspective of the individual who created the concept map (Ross, 2004).

\section{PERSPECTIVE ON SCHOOLING AS AN INDUSTRIAL LINE AND CAPITAL INVESTMENT}

The bulk of schooling may resolve around only three basic processes, there are teaching, curriculum and learning (Hamilton, 1990). Meanwhile, Barth (1990; Hopkins, 2005) argues for basing school reform on the skills, aspirations and energy of those closest to the school: teachers, senior management, governors and parents. A 'community of learners' approach school improvement from a radically different set of assumptions than those of the list makers. These assumptions are (1) schools have the capacity to improve themselves. A major responsibility of those outside the school is to help provide these conditions for those inside; (2) when the need and purpose is there, when the conditions are right, adults and students alike learn and each energises and contributes to the learning of the other; (3) what needs to be improved about schools is their culture, the quality of interpersonal relationships, and the nature and quality of learning experiences; and (4) school improvement is an effort to determine and provide, from community directly or indirectly who inhabit schools will promote and sustain learning among themselves. 


\section{Intianting Sustainable Performance on Language Cirriculum Implementation}

There are three conclusions can be drawn in term of organization development. First, the approaches emphasize the importance of a school's organisation circumstance. Second, a major emphasis in many school improvement interventions is based on an approach that attempts to humanise the organisational context within which teachers and students live. Third, the possibly under emphasised at the time, is the empirical support given to the effectiveness of intervention strategies that diagnosed the internal conditions of the organisation as a precursor to development (Hopkins, 2005).

Moreover, a report by the Organisation for Economic Co-operation and Development in 1989 concerns with decentralisation and school improvement outreaches that there are three principle reasons for decentralisation issues, namely: (1) the decentralisation of decision making as part of school improvement establishes new roles and responsibilities for senior education officials at the centre and for school leaders, teachers and parents at the school level.; (2) shifts of responsibility to the school raise the possibility that some functions, formerly carried out at the centre, will not be effectively performed; and (3) the management of change, which requires a strategy which considers change as a dynamic and evolutionary process (Hopkins, 2005).

\section{CURRICULUM REPOSITION}

At a time when the educational system as a whole faced not only retrenchment but also pressure for change. When the school is regarded as the 'centre' of change, then strategies for change need to take this new perspective into account in the following: (1) a systematic, sustained effort aimed at change in learning conditions and other related internal conditions in one or more schools, with the ultimate aim of accomplishing educational goals more effectively; (2) the school as the centre of change. This means that external reforms need to be sensitive to the situation in individual schools, rather than assuming that all schools are the same.; (3) a systematic approach to change. School improvement is a carefully planned and managed process that takes place over a period of several years; (4) a key focus for change are the 'internal conditions' of schools. These include not only the teaching-learning activities used in the school, but also the schools' procedures, role allocation and resource use that support the teaching learning process; (5) accomplishing educational goals more effectively. Educational goals reflect the particular mission of a school, and represent what the school itself regards as desirable; (6) a multilevel perspective. The school is embedded in an educational system that has to work collaboratively, or symbiotically, if the highest degrees of quality are to be achieved. This means that the roles of teachers, heads, governors, parents, and other supporting stakeholders; (7) integrative implementation strategies. This implies a linkage between 'top down' and 'bottom-up'; remembering of course that both approaches can apply at a number of different levels in the system; and (8) the drive towards institutionalisation. Change is only successful when it has become part of the natural behaviour of teachers in the school (Hopkins, 2005). To meet these strategies, it is needed some supporting infrastructures (Heywood, 2005), namely: establishment standards, accreditation, finance, admissions, and examinations. 


\section{CONCLUSION}

The language curriculum at schools have reached to some dynamics of its implementation during the years, even teachers of English have had some teaching experience as well. During the spam of teachers' experience in the classroom teaching, certainly some particular aspects which lead to their contribution and barriers in the cognitive and noncognitive domain may result to the students' outputs. Due to these aspects, educators and stakeholders shall release and do some notifications and improvements in term of their categories faced in the classroom. Inspiring teachers shall critically view the standard curriculum which contributes to the pedagogical aims, syllabus, and developing materials regularly in semesters. Then, they shall strongly refer to what we familiarly call by curriculum engineering in which a teacher may start teaching the students by the relevant materials and put the students' readiness to learn the materials. Four skills will be on teachers' focus, namely writing, reading, listening, and speaking. Herewith, the concept of curriculum needs to include the explicit teaching of the intellectual and socialemotional skills. After that, curriculum issues will reflect to teachers' concern with its position in the globalization era. These issues relate to the teachers' perspective in providing for continuous quality assurance, preparing to a major review of curriculum in the irrespective of external pressures.

Educational reform issue as well, is the priority on sustainable performance of the language curriculum implementation. It involves a modern language as an appropriate media of instruction used for all students. The success of an educational reform is associated with different factors, including quality provision of education opportunities, resources and materials, and supporting learning environments. On the other hand, teachers shall be aware of disadvantage issues on the educational reform. These issues will include the insufficient commitment to produce the changes by authorities who have legitimating on their political power, limited support from stakeholders in accordance with the financial sources, and the resistance of teachers and parents' roles. The last but not least, teachers' empowerment position in implementing the sustainable performance of language curriculum shall refer and strengthen any main tasks and responsibility for supporting the teaching profession significantly.

\section{REFERENCES}

Basturkmen, H. 2010. Developing courses in English forspecificpurposes. New York: PALGRAVE MACMILLAN.

Folsom, C. 2009. Teaching for intellectual and emotional learning(TIEL): Amodelfor creating powerful curriculum. Plymouth: Rowman \& Littlefield Education.

Jarvis, P. 2004. Adult education and lifelong learning: Theory and practice ( $3^{\text {rd }}$ ed.). London: RoutledgeFalmer.

Hamilton, D. 1990. Learning about education: An unfinished curriculum. Philadelpia: Open University Press

Heywood, J. 2005. Engineering education: Research and developmentincurriculumandinstruction. New Jersey: John Wiley \& Sons, Inc. 
Intianting Sustainable Performance on Language Cirriculum Implementation

Hopkins, D. 2005. The practice and theory of school improvement: International handbook of educational change. InHopkins, D, Tensions in and prospects for school improvement (Pp. 121). Dordrecht: Springer.

Nation, I.S.P \& Macalister, J. 2010. Language curriculum design. New York: Routledge Taylor \& Francis Group.

Phillips, D \& Sankey, C. F. 1993. Diversification in modern language teaching: Choice and the national curriculum. London: Routledge.

Ross, A. 2004. Curriculum: Construction and critique. London: Falmer Press.

Saleh, M. 1995. Professional curricula: Journal article volume IV. In Skilbeck, M, Who controls educationalreform?(Pp.31-43). Semarang: FBS IKIP Semarang.

1995. Professional curricula: Journal article volume IV. InPinar, W. F \& Reynolds W. M,Curriculumastext(Pp. 1-14). Semarang: FBS IKIP Semarang.
Saroyan, A \& Amundsen, C. 2004. Rethinking teaching in higher education: From a course design workshop to a faculty development framework. In Amundsen, C \& Soroyan, A, Analysis of course content (Pp. 33-51). Virginia: Stylus Publishing, LLC.

Thomas, H \& Martin, J. 1996. Managing Resources for School Improvement: Creating a CostEffective School. London: Routledge.

Zajda, J \& Geo-Jaja, M.A. 2010. The politics of education reforms. InZajda, J, Globalization and the politics of education reforms. (Pp. xiii-xxi). London: Springer.

2010. The politics of education reforms. In Cummings, W.K., How educational systems form and reform. (Pp. 19-39). London: Springer.

2010. The politics of education reforms. InEspinoza, $\mathrm{O}$, Alternative approaches on society, state, educational reform, and educational policy. (Pp. 87-108). London: Springer.

Wray, D. 1995. English 7-11: Developing primary teaching skills. London: Routledge. 